\title{
ELEKTROMOS SZEGÉLYNYÍRÓ GÉP ZAJVIZSGÁLATA
}

\author{
Kakuk József \\ Fejlesztömérnökség szakmai vezetö, Robert Bosch Power Tool Kft. \\ 3529 Miskolc, Robert Bosch Park 1., e-mail: jozsef.kakuk@hu.bosch.com
}

\begin{abstract}
Absztrakt
Az elektromos füszegélyvágó gépek által kibocsátott zaj szintjéről az Európai Parlament 2000-ben elfogadott irányelv rendelkezik. A gyártó kötelessége, hogy a forgalomba hozott gép által kibocsátott hangteljesitmény ne haladja a meg az $L_{W A}=96 d B-t$. További elöirás, hogy a gyártó tüntesse fel a termékre garantált hangteljesitmény szintet, melyet több gép vizsgálatából határoz meg, és azt egy független tanúsitó intézet ellenórizze. Az elektromos füszegélyvágók által kibocsátott zaj túlnyomó része a forgó damil által jön létre, melyet néhány konstrukciós paraméter befolyásol.
\end{abstract}

Kulcsszavak: szegélynyírók, zajkibocsátás, kültéri, irányelv

\begin{abstract}
The level of noise emitted by electric lawn trimmers is regulated by a directive adopted by the European Parliament in 2000. It is the responsibility of the manufacturer to ensure that the sound power emitted by the machinery placed on the market does not exceed $L_{W A}=96 \mathrm{~dB}$. A further requirement is for the manufacturer to state the guaranteed sound power level for the product, which is determined by testing several machines and is checked by an independent certification body. Most of the noise emitted by electric lawn trimmers is generated by the rotating line which is influenced by a few design parameters.
\end{abstract}

Keywords: lawntrimmers, noise, outdoor, directive

\section{Bevezetés}

\subsection{A Kültéri Zaj Direktíva}

Az Európai Parlament és a Tanács, 2000. május 8.-án fogadta el a 2000/14/EK számú irányelvet, a kültéri használatra tervezett berendezések zajkibocsátására vonatkozó tagállami jogszabályok közelítéséröl. Az irányelv célja a belső piac keretein belül közelíteni a szabadban használatos berendezések zajkibocsátására vonatkozó követelményeket, az ilyen berendezések szabad mozgása érdekében. Ezen felül természetesen az ilyen berendezések engedélyezett zajszintjének csökkentése védi az egészséget és a polgárok jólétét, valamint óvja a környezetet. Továbbá cél, a nyilvánosság számára is biztosítani az ilyen berendezések által kibocsátott zajról szóló adatokat.

Az Európai Bizottság 1993. február 1-jei állásfoglaláshoz csatolt ötödik környezetvédelmi cselekvési program a zajt úgy határozza meg, mint az egyik legnyomasztóbb környezeti akadályt a városi területeken, és a különböző zajforrásokkal kapcsolatos cselekvések végrehajtását szorgalmazza. „A jövő zajpolitikája" című Zöld könyvében a Bizottság úgy határozza meg a környezeti zajt, mint Európa egyik fő helyi környezeti problémáját, és kifejezte azon szándékát, hogy javaslatot tegyen egy keretirányelvre a szabályozás érdekében. A tagállamoknak biztosítaniuk kell, hogy az irányelv hatálya 
alá tartozó berendezések megfelelnek az irányelv követelményeinek, a forgalomba hozatal vagy használatba vétel során.

Azokat a követelményeket, amelyek a munkaszerü tevékenységet végző dolgozókat védik, a szabadban használatos berendezések használatának szabályozásával, ez az irányelv nem befolyásolja. A tagállamok saját területükön nem tiltják, korlátozzák vagy akadályozzák azon berendezés forgalomba hozatalát vagy használatba vételét, amely megfelel ezen irányelv követelményeinek, viseli a CE megfelelőségi jelet és a garantált hangteljesítményszintet, és amelyhez mellékelték az EK megfelelöségi nyilatkozatot.

A gyártó felelős azért, hogy a berendezés megfeleljen az irányelv rendelkezéseinek és minden rá vonatkozó irányelvnek. A gyártó, rögzíti a $\mathrm{CE}$ megfelelőségi jelölést és a garantált hangteljesítmény jelzését a berendezésen. A tagállamok megtesznek minden szükséges intézkedést annak biztosítására, hogy a nem megfelelő berendezések az elöírásoknak megfeleljenek, ellenkező esetben kivonják azokat a forgalomból.

A gyártók számára kötelező, hogy a berendezésen feltüntessék a kültéri használat esetén jelentkező garantált hangteljesítményszintet azért, hogy lehetővé tegyék a fogyasztó és a felhasználó számára a berendezés ezen adatok ismeretében történő választását. Ezen jelölésnek világosnak és félreérthetetlennek kell lennie. A megjelölt értékeket a gyártó szavatolja a termék teljes élettartama során. Az elöírás alapján a zajkibocsátás jelzése, garantált hangteljesítményszint formájában együtt szerepel a CEjelöléssel. A , hangteljesitmény $L_{W A}$ ": jelentése az A-hangteljesítményszint dB-ben $1 \mathrm{pW}$-ra vonatkoztatva, ahogyan azt az EN ISO 3744:1995 és EN ISO 3746: 1995-ben meghatározza. A ,,garantált hangteljesitményszint": az a hangteljesítmény, amelyet a megadott követelményekkel összhangban határoznak meg, és amely magába foglalja a különböző gyártásból és mérési módszerekből adódó bizonytalanságot is továbbá, amelyet a gyártó vagy annak a közösségi illetőségü hivatalos képviselöje megerősít, miszerint - az alkalmazott és müszaki dokumentációban említett müszaki eljárásokat figyelembe véve - a berendezés ezt az értéket nem lépi túl.

1. táblázat. A Kültéri Zaj Direktiva fünyírókra vonatkozó határértékei [1]

\begin{tabular}{|c|c|c|c|}
\hline \multirow[b]{2}{*}{ Type of equipment } & \multirow{2}{*}{$\begin{array}{c}\text { Net installed } \\
\text { power } \\
P^{\prime} \text { (in } \mathrm{kW} \\
\text { Electric power } \\
P_{\mathrm{d}}\left({ }^{(}\right) \text {in } \mathrm{kW} \\
\text { Mass of appliance } \\
m \text { in kg } \\
\text { Cutting width } L \\
\text { in } \mathrm{cm}\end{array}$} & \multicolumn{2}{|c|}{$\begin{array}{l}\text { Permissible sound power level } \\
\text { in } \mathrm{dB} / 1 \mathrm{pW}\end{array}$} \\
\hline & & $\begin{array}{c}\text { Stage I } \\
\text { as from } \\
\text { 3 January 2002 }\end{array}$ & $\begin{array}{c}\text { Stage II } \\
\text { as from } \\
\text { 3 January } 2006\end{array}$ \\
\hline \multirow[t]{4}{*}{ Lawnmowers, lawn trimmers/lawn edge trimmers } & $L \leq 50$ & 96 & $94\left({ }^{2}\right)$ \\
\hline & $50<L \leq 70$ & 100 & 98 \\
\hline & $70<L \leq 120$ & 100 & $98\left({ }^{2}\right)$ \\
\hline & $L>120$ & 105 & $103\left({ }^{2}\right)$ \\
\hline
\end{tabular}

A füszegélyvágó gépekre az irányelv következő meghatározása érvényes: “Gyepvágó/gyepszegélyvágó" Olyan elektromos meghajtású, kézzel tolható vagy kézben tartott fünyírógép nemfémes szálú vágóelemmel(ekkel), vagy szabadon forgó nemfémes vágókésekkel, amelyek mozgási energiája egyenként nem nagyobb, mint $10 \mathrm{~J}$ és amelyet fü vagy hasonló lágy növényzet vágására szántak. A vágóelem(ek) a talajjal nagyjából párhuzamos síkban (gyepvágó) vagy merőleges síkban 
(gyepszegélyvágó) mozognak [1]. A szegélynyíró gépekre vonatkozó határétékeket az 1. Táblázat tartalmazza, miszerint az $50 \mathrm{~cm}$ vágási szélességet meg nem haladó gépek esetében a megengedett hagteljesítményszint $96 \mathrm{~dB}$.

\subsection{Az elektromos füszegélyvágó gépek}

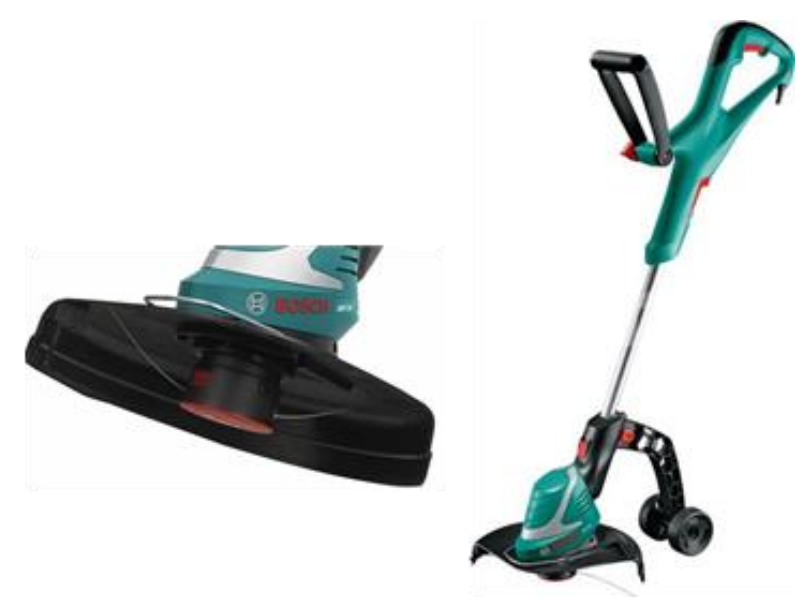

1. ábra. Bosch ART30 Hálózati feszültségü szegélynyíró gép és vágófeje

A Robert Bosch Power Tool Elektromos Szerszámgyártó Kft.-ben 2001. novembere óta készülnek zöld, barkács- és otthoni felhasználásra gyártott, valamint kék, az ipari felhasználásra szánt termékek. A miskolci Bosch egyik nagy előnye, hogy a termékfejlesztés 2006. óta azonos telephelyen történik. A termékkoncepciók kialakításától a gyártás beindításáig minden tevékenysége helyben történik.

Az elektromos fúszegélyvágók két nagy csoportját az akkumulátoros és vezetékes gépek alkotják. A gépek jelölése, a típusjelzés mellett feltüntetett szám a vágási átmérőt jelöli centiméterben. A vágást szinte minden esetben egy 8-11.000 1/min fordulatszámú, damil végzi, melynek az adagolása lehet kézi, félautomata és teljesen automata.

\section{A füszegélyvágó gépek hangteljesítményét befolyásoló tényezők}

A gépek által kibocsátott zaj mérése két üzemmódban történik: normál vágási, és az arra alkalmas berendezések esetében, úgynevezett edging üzemmódban.

Ezen üzemmód kritikus a zajvizsgálat szempontjából, mivel a gép fölötti térrészben, egy félgömb mentén elhelyezett mikrofonok közül egy, vagy több a gép fő zajforrása a vágófej előtt helyezkedik el. A gép által kibocsátott zaj túlnyomó többsége a nagysebességgel forgó damiltól ered. Ennek konstrukciós paraméterei alapvetően meghatározzák a kialakuló zajt. Ezek a hatás csökkenő sorrendjében, a kialakult üresjárati fordulatszám, vágási átmérő, azaz a kilógó damilszakasz hossza, a damilok száma (1 vagy 2), a damil(ok) átméröje, a damil keresztmetszetének alakja, a damil végének távolsága a védőburkolattól, a damil levágott végének alakja.

A zajmérés során alkalmazandó üresjárati fordulatszám alapvetően meghatározza a kialakult zajt, mely a mérési eredményeink szerint közel egyenes arányosságot mutat a hangteljesítménnyel. A fü hatékony vágásához legalább $24 \mathrm{~cm}$ átmérő és 8000 1/min fordulatszám szükséges. 


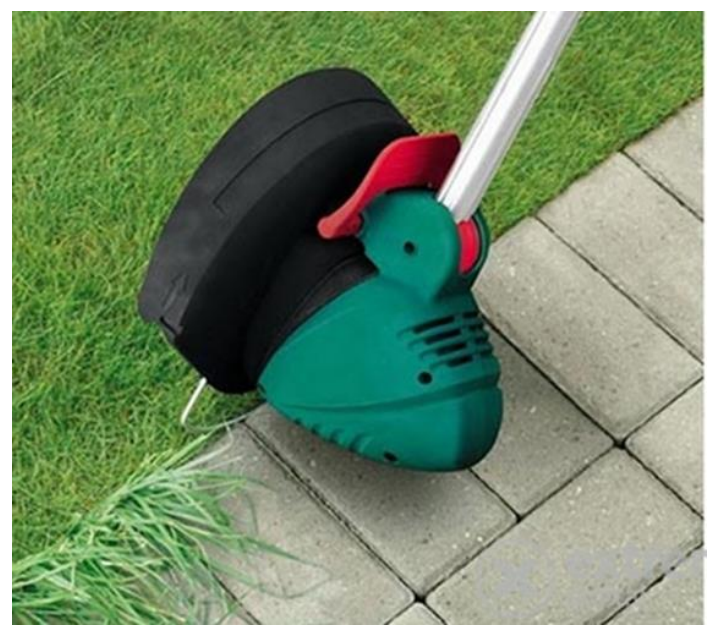

\section{2. ábra. Füszegélyvágók ,edging” üzemmódja}

A vezetékes gépek esetén alkalmazott váltakozó áramú univerzális motorok üresjárati fordulatszámát a fellépő veszteségek (csapágyak, ventilátor, damil légellenállás, rezgések) nagymértékben befolyásolják, így ezek csökkentése fordulatszám és zajnövekedést eredményeznek. Ezen jelenségek okozta zaj csökkenés nem ellensúlyozza a nagyobb sebességgel forgó damil okozta növekményt. A vágási átmérő szerkezeti sajátosság, nem változtatható. A damil huzal átméröjének növelésével a zaj kis mértékben lineárisan növekszik, az átmérő alsó határának a fellépő kopás szab határt. A huzalkeresztmetszet alakja szempontjából a hengeres a legelönyösebb, minden egyéb, a kereskedelmi forgalomban kapható egyéb (négyzetes, csúcsos, bordás) kialakítással szemben. Amennyiben a nagysebességgel forgó damil vége néhány milliméternél közelebb kerül egy álló alkatrészhez (vágókés, védőburkolat) a kibocsátott zaj ugrásszerüen megnő. A hengeres damil vége ideális esetben egy szabályos, merőleges palásttal végződik; mivel minden más esetben (pl. ferde vágás) a véglapra ható légellenállás miatt a damil tengelyirányú lengésekbe kezd. Az ilyen jellegü rezgések 10-20 kHz tartományban nagymértékü hangteljesítmény növekedést okoznak.

A forgó damil keltette zaj mellett a következő a sorban a védőburkolat kialakítása. A védőburkolat minimális méretét szabvány rögzíti. A burkolat mérete és alakja a damil által keltett zaj visszaverésében játszik szerepet „edging” üzemmódban.

\section{Köszönetnyilvánítás}

"A cikkben ismertetett kutató munka az EFOP-3.6.1-16-2016-00011 jelü „Fiatalodó és Megújuló Egyetem - Innovatív Tudásváros - a Miskolci Egyetem intelligens szakosodást szolgáló intézményi fejlesztése" projekt részeként - a Széchenyi 2020 keretében - az Európai Unió támogatásával, az Európai Szociális Alap társfinanszírozásával valósul meg."

\section{Irodalom}

[1] A kültéri használatra tervezett berendezések zajkibocsátására vonatkozó tagállami jogszabályok közelítéséröl L 162/1 Az európai közösségek hivatalos lapja (2000.7.3.) Az európai parlament és a tanács 2000/14/EK irányelve (2000. május 8.) 13/25. kötet, pp.:287 